\title{
FEATURE Techniques for assessing the environmental outcomes of conservation practices applied to rangeland watersheds
}

\author{
Mark A. Weltz, Leonard Jolley, Dave Goodrich, Ken Boykin, Mark Nearing, Jeff Stone, Phil Guertin, \\ Mariano Hernandez, Ken Spaeth, Fred Pierson, Christo Morris, and Bill Kepner
}

razing lands are the most dominant land cover type in the United States, with approximately 311.7 Mha being defined as rangelands (Mitchell 2000). Approximately 53\% (166.2 Mha) of the nation's rangelands (USDA 2009) are owned and managed by the private sector, while approximately $43 \%$ are managed by the federal government (USDA NRCS 2011a). The remaining rangelands are owned and managed by tribal, state, and local governments. Information on the type, extent, and spatial location of land degradation on rangelands is needed to inform policy and management decisions on rangelands; however, there is no systematic or coordinated national dataset on status or condition of rangelands for the United States to make informed policy decisions (NRC 1994; Herrick et al. 2010). Rangelands in the west are sparsely populated, and assessments of rangeland conditions have historically not been uniformly conducted across all land ownership classes in any systematic monitoring program. Therefore, it is difficult to assess the current health of rangelands and which areas could benefit from targeted conservation as USDA Natural Resources Conservation Service

Mark A. Weltz is a rangeland hydrologist at the USDA Agricultural Research Service, Reno, Nevada. Leonard Jolley is a rangeland ecologist at the USDA Natural Resources Conservation Service, Beltsville, Maryland. Dave Goodrich is a hydraulic engineer at the USDA Agricultural Research Service, Tucson, Arizona. Ken Boykin is a wildlife biologist at the New Mexico State University, Las Cruces, New Mexico. Mark Nearing is an agricultural engineer and Jeff Stone is hydrologist at the USDA Agricultural Research Service, Tucson, Arizona. Phil Guertin and Mariano Hernandez are hydrologists at the University of Arizona, Tucson, Arizona. Ken Spaeth is a rangeland hydrologist at the USDA Natural Resources Conservation Service, Fort Worth, Texas. Fred Pierson is a rangeland hydrologist at the USDA Agricultural Research Service, Boise, Idaho. Christo Morris is a physical science technician at the USDA Agricultural Research Service, Reno, Nevada. Bill Kepner is an ecologist at the Office of Research Development, Environmental Protection Agency, Las Vegas, Nevada.
(NRCS) has recently done for cropland within the Upper Mississippi River Basin (USDA NRCS 2010) and the Chesapeake Bay (USDA NRCS 2011b) through the Conservation Effects Assessment Project (CEAP).

CEAP is a USDA initiative that is focused on quantifying environmental impacts of conservation on agricultural lands. The CEAP component aimed at assessing conservation on grazing lands was initiated in 2006 (Weltz et al. 2008). The challenges associated with assessments and monitoring on grazing lands and specifically rangelands are extreme due to the large spatial extent of the resource, mixed land ownership, high variability of biological attributes due to extremes in annual precipitation in arid and semiarid rangelands, no uniform sampling protocol, and no central agency assigned for conducting the assessment. The assessment of rangelands is further complicated by the difficulty in defining a baseline condition (reference condition) to document what changes have occurred. Additional challenges include developing cost-effective means of integrating quantitative data into an assessment protocol, high cost associated with collecting and processing national datasets, minimal analytical tools to interpret the results, and no dedicated team to develop and write the assessment.

\section{ASSESSMENT FRAMEWORK}

Through the Grazing Land CEAP project, USDA intends to first synthesize what we know about the impact on the hydrologic cycle from the application of conservation practices on grazing lands and fill knowledge gaps about the impact of grazing land practices on watershed health and impacts on ecosystem services at the landscape scale. Second, CEAP will develop approaches, methodologies, and databases to produce scientifically credible estimates of environmental benefits/impacts of conservation. Planning and assessment in land and water resource management are evolving from simple, local-scale problems toward complex, spatially explicit regional and national ones. Such problems have to be addressed with distributed models that can compute environmental benefits at different spatial and temporal scales and look at net cumulative impacts of management over a range of time scales to avoid unintended consequences. The extensive data requirements and the difficult task of building input parameter files, however, have long represented an obstacle to the timely and cost-effective use of such complex models by resource managers for conducting large scale assessments.

A new rangeland USDA NRCS Natural Resource Inventory (NRI) protocol was established in 2003 (USDA NRCS 2007). On nonfederal rangeland, this new protocol has been collected annually on field segments in the seventeen western states (Spaeth et al. 2003, 2005; Herrick et al. 2010) using a national sampling frame (Nusser et al. 1998; Nusser and Goebel 1997) since 2003. The spatially unbiased sample population of rangeland segments (approximately 20,000 as of 2010) was selected using a national sampling strategy together with a GIS analysis of land cover and ownership. The first time series of data, 2003 to 2006, has been evaluated to provide qualitative assessment of rangeland health on nonfederal rangelands (Herrick et al. 2010). USDA NRCS rangeland NRI data has been used to inform the analytical framework for modeling runoff and soil erosion at the scale of hillslopes (USDA 2011). This dataset in combination with national land cover datasets (i.e., Landfire 2011 [Landfire 2011], North American Land Cover 2011 [NALC 2011], and Southwest Regional Gap Analysis Project 2011 [SWReGAP 2011]) has been used to define distribution of plant communities as initial input to evaluate alternative futures with and without conservation practices for watershed assessments in the intermountain west.

\section{AUTOMATED GEOSPATIAL WATERSHED ASSESSMENT}

The USDA and its partners have developed a geographic information system 
(GIS) tool to facilitate the process of assessing the environmental impacts/benefits of conservation. The GIS provides the framework within which spatiallydistributed data are collected and used to prepare model input files and evaluate model results. The Automated Geospatial Watershed Assessment (AGWA) tool uses widely available standardized spatial datasets (soils, topography, climate, and land cover) that can be obtained via the internet from government agencies (Miller et al. 2007). The data are used to develop input parameter files for 3 scale-specific hydrologic models depending on the questions to be addressed: (1) Rangeland Hydrology and Erosion Model (RHEM) (Nearing et al. 2011) for hillslope scale assessments (unit area concept); (2) Kinematic Runoff and Erosion Model (KINEROS2) (Smith et al. 1995) for small watershed assessments $\left(<100 \mathrm{~km}^{2}\right)$; and (3) Soil Water Assessment Tool (SWAT) (Gassman et al. 2007; Srinivasan et al. 2010) for river basin assessments. The AGWA tool allows the user to select a model that is best designed to estimate impacts and benefits of conservation at a specific scale.

Using digital data in combination with the automated functionality of AGWA greatly reduces the time required to conduct an assessment of the benefit of conservation. Through a robust interface, the user selects an outlet from which AGWA delineates and discretizes the watershed using the Digital Elevation Model (DEM) information. The watershed elements are then intersected with soil, land cover, and precipitation (uniform or distributed) data layers to derive the requisite model input parameters. The model is run, and the results are imported back into AGWA for visual display. Model results that can be displayed in AGWA are shown in the table 1 . This option allows managers to identify problem areas where management activities can be focused or to anticipate sensitive areas in association with planning efforts. The physical process models used in this study are mathematical representations of the real world designed to estimate complex and varying environmental events and conditions. To estimate the effects of conservation practices, model simulation results were used

\section{Table 1}

Hydrologic variables that can be spatially displayed in Automated Geospatial Watershed Assessment (AGWA) tool by model component: Rangeland Hydrology and Erosion Model (RHEM) for hillslope; Kinematic Runoff and Erosion Model (KINEROS2) for watershed; and Soil Water Assessment Tool (SWAT) for river basin.

\begin{tabular}{lll}
\hline RHEM & KINEROS & SWAT \\
\hline Precipitation & Precipitation & Precipitation $(\mathrm{mm})$ \\
Infiltration & Infiltration & Infiltration $(\mathrm{mm})$ \\
Runoff & Runoff & Runoff $(\mathrm{mm})$ \\
Peak flow & Peak & Peak flow $\left(\mathrm{m}^{3} \mathrm{~s}^{-1}\right)$ \\
Sediment yield & Sediment yield & Sediment yield $(\mathrm{kg} / \mathrm{ha})$ \\
Sediment discharge & Sediment discharge & Sediment discharge $(\mathrm{kg} / \mathrm{s})$ \\
& Channel scour & Channel scour $\left(\mathrm{mm} / \mathrm{m}^{2}\right)$ \\
& & Evapotranspiration $(\mathrm{mm})$ \\
& & Transmission loss $(\mathrm{mm})$ \\
& & Ground water $(\mathrm{mm})$ \\
& & Base flow $(\mathrm{mm})$ \\
\hline
\end{tabular}

to make relative comparisons between two model runs-one that includes conservation practices and one that excludes conservation practices. All other aspects of the input data and the model parameters are held constant in the two model runs. The assessment includes all conservation practices in use regardless of how or why they came to be in use. It is not restricted to only those practices associated with federal programs and includes the conservation efforts of states, independent organizations, individual landowners, and ranch operators. AGWA is designed to provide qualitative estimates of runoff and erosion relative to landscape change. Full model documentation, relevant peer reviewed publications, and the software are available at http://www.tucson.ars. ag.gov/agwa/.

\section{MODEL IMPLEMENTATION AND WATERSHED ASSESSMENT}

This article focuses on the status of hydrologic tools to assess the impacts and benefits of conservation practices at the watershed scale using the capability of the AGWA interface and the SWAT river basin and KINEROS2 models. The initial rangeland assessment will focus on watersheds in the intermountain west. The initial analysis utilized a 5-year return precipitation event to assess the benefit of conservation.

Project findings and results will be used to report progress on the environmental benefits of USDA conservation programs, aid discussions on conservation policy development, guide conservation pro- gram implementation, and ultimately, help farmers and ranchers make informed conservation choices based on sound science.

The first federal conservation efforts on rangelands were focused on prescribed grazing and forage availability, water management, and soil erosion control. More recently, the focus has shifted from soil preservation and sustainability to a broader goal of ecosystem services derived from prescribed grazing, habitat enhancement, and associated conservation practices deployed on rangelands (table 2) (Leonard Jolley, USDA NRCS, personal communication, July 2009). Primary conservation practices to be evaluated on rangelands for

\section{Table 2}

Most common conservation practices deployed by USDA Natural Resources Conservation Service from 2004 through 2008 on grazing lands.

\begin{tabular}{lc}
\hline Practice name & Treatment area (ha) \\
\hline Prescribed grazing & $13,815,150$ \\
Upland wildlife habitat & $6,980,243$ \\
$\quad$ management & \\
Pest management & $2,474,783$ \\
Use exclusion & 912,322 \\
Brush management & 410,754 \\
Range planting & 260,274 \\
Forage harvest & 213,292 \\
$\quad$ management & \\
Pasture and hay planting & 131,974 \\
Prescribed burning & 34,660 \\
Grazing land mechanical & 17,191 \\
$\quad$ treatment & \\
Heavy use area protection & 6,174 \\
Riparian herbaceous cover & 3,721 \\
\hline
\end{tabular}


CEAP watershed assessments included prescribed grazing, invasive species control, fire management, brush management, upland habitat management, stock ponds, range seeding, buffer strips, and riparian management. These conservation practices are designed to reduce losses of soil, nutrients, pesticides, pathogens, and other biological and chemical materials from rangelands and enhance and conserve natural resources, water quality, and wildlife habitat.

To facilitate the selection of where a conservation practice may achieve optimal benefit the user may select an "Area of Interest," and AGWA will interactively locate the impacted watershed outlets and then use the stream network and boundary polygons to cover the area with the fewest, and smallest, watersheds necessary to parameterize and simulate the area as one unit (i.e., pasture or grazing allotment). This option allows the user to determine if soil erosion is initiated above the area of interest and is being routed through the area or if the soil erosion is occurring within the area of interest (figure 1).

If soil erosion is being initiated within the area of interest, then the user can evaluate if and where conservation practices should be placed to have optimal impact for the least cost. An example of this would be evaluating the effectiveness of prescribed grazing (figure 2) or installing brush control and revegetation practices, and the impact these practices would have on surface hydrologic processes and associated soil erosion processes (figure 3). A second conservation practice that might be evaluated is the installation of a stream side buffer (figure 4) to reduce peak discharge rates and sediment yield. Wildfires have the potential to cause catastrophic flooding in the first year following the burn if sufficient vegetation has not been reestablished. The AGWA tool can be used to evaluate flooding and catastrophic soil loss following wildfires and help guide placement of structures and soil stabilization treatments to minimize loss of life and property by using burn severity maps to guide changes in key model parameters (figures 5 and 6). AGWA can be used to help determine the location of stock ponds to provide critical water supply to livestock and wildlife and the impact the

\section{Figure 1}

(a) Users selects an "Area of Interest" and then (b) the Automated Geospatial Watershed Assessment tool interactively locates watershed outlets by using the stream network and boundary polygons to cover the area with the fewest, and smallest, watersheds necessary. The newly discretized watersheds form a watershed group that is parameterized and simulated as one unit, providing the user a simple means of determining how management impacts both the allotment and the surrounding watersheds.
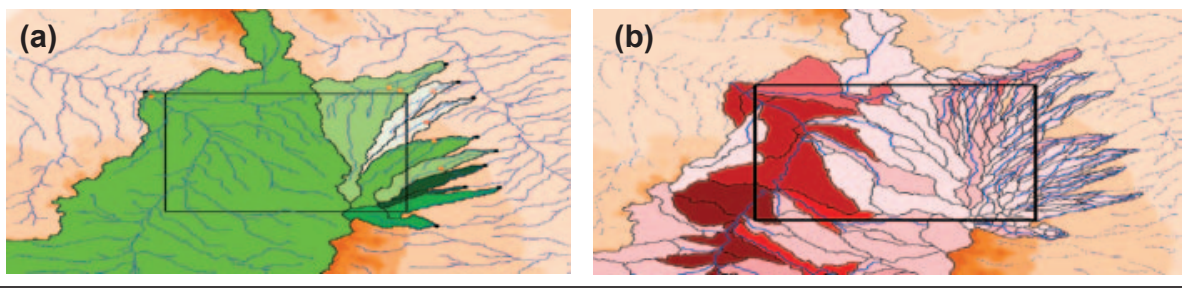

\section{Figure 2}

Users selects an "Area of Interest" and then the Land Cover Modification tool with a user-defined impact rate will create a randomly distributed patchy surface of (a) the original state and (b) the new state for assessment of the benefit of the conservation practice, such as, watershed receiving prescribed grazing or installing brush control and revegetation practices.

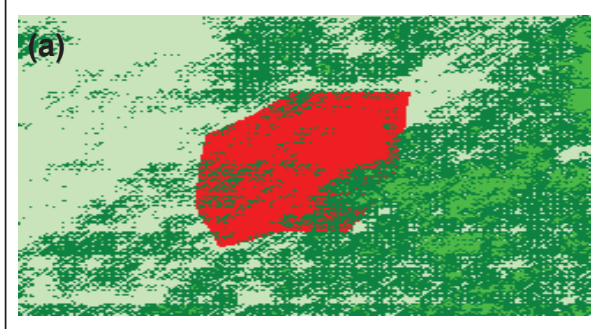

stock pond will have on reducing peak flows that might cause downstream flooding (figure 7).

The AGWA model package allows managers to rapidly identify problem areas for further monitoring and management activities. Additional functionality can be derived from the AGWA decision tool by using it to generate alternative future land use and cover scenarios and display differences between simulation outputs (potential change). This option is designed to provide decision support when combined with planning efforts to identify benefits and consequences of proposed management actions. AGWA is designed to provide qualitative estimates of runoff and erosion relative to landscape change as a function of either climate or management actions in ungauged river basins. If calibration data are not available, it can provide useful information on relative difference between alternative management actions for estimating the potential impact on hydrologic and soil erosion processes. This information can then be used to guide the selection of appropri-

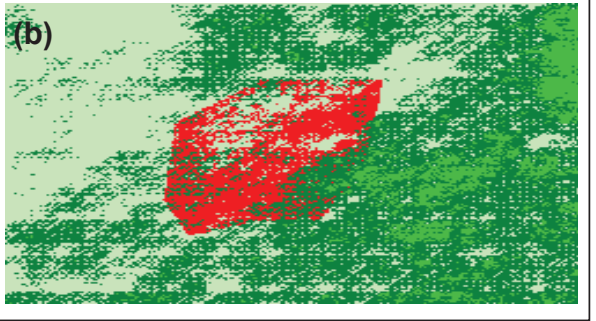

ate conservation practices to optimize the cost-benefit ratios of large scale restoration projects. The AGWA model package can provide reliable quantitative estimates of runoff and erosion if appropriate calibration datasets are available.

\section{BRUSH CONTROL AND REVEGETATION ASSESSMENT: USDA ARS WALNUT GULCH EXPERIMENTAL WATERSHED, TOMBSTONE, ARIZONA}

The Land Cover Modification tool in AGWA can be used to simulate a wide range of conservation practices and evaluate their effectiveness with design storms (e.g., 10-year, 1-hour return period). Users can use this option to evaluate the impact of prescribed grazing. The user can change entire user-defined area using the "Area of Interest" function to new ecological state (land cover class), or the impact of the conservation practice can be simulated as a random or patchy impact. By using a fractal clustered land-cover pattern coefficient available in the model interface, the user can select the success rate of a conservation practice, creating a randomly 
distributed patchy surface of the original state (a) and the new state (b) (figure 2).

The Land Cover Modification Tool in AGWA was used to change the land cover from Chihuahuan Creosotebush (Larrea tridentata) to grassland at the USDA Agricultural Research Service (ARS) Walnut Gulch Experimental Watershed (Subwatershed \#4) to evaluate if the model could estimate environmental benefits from a proposed brush removal and reseeding project. This tool allows the user to change an entire polygon or a specific land cover from one type to another. Using the tool and the hydrologic models in AGWA (KINEROS2 or SWAT), impacts to runoff, infiltration, sediment yield, and peak flows can be simulated before and after land cover change. This type of analysis provides land managers with the ability to determine which areas are better suited for land cover modification for management purposes such as brush management for fire control or grazing land improvement, as well as the spatial location and magnitude of the consequences of the conservation practices.

AGWA/KINEROS2 simulations were performed on Walnut Gulch Experimental Subwatershed \#4 before and after brush removal and reseeding to grassland. Walnut Gulch is approximately $150 \mathrm{~km}^{2}(37,070$ ac), and Subwatershed \#4 is approximately $2.3 \mathrm{~km}^{2}$ (572 ac). The SWReGAP land cover dataset (circa 1999-2001) was used as a basis for defining land cover for the watershed. Subwatershed \#4 was selected because it is primarily brush (Chihuahuan Creosotebush, Mixed Desert, and Thorn Scrub). A new grassland class was created for this simulation, based on existing grassland classifications and the KINEROS2 manual which specifies a decrease in interception, an increase in cover, and an increase in hydraulic roughness (Manning's n) (table 3). It was assumed that the entire watershed area was successfully converted to grassland with the characteristics in table 3. Simulations were performed using the 5-year, 30-minute rainfall event. Results indicated large decreases in peak flow $(\mathrm{mm} / \mathrm{hr})$, peak sediment yield $(\mathrm{kg} / \mathrm{s})$, and average annual runoff $\left(\mathrm{m}^{3} / \mathrm{s}\right)$ after the watershed was converted to grassland (figure 3). Percent change in peak

\section{Figure 3}

Walnut Gulch Experimental Watershed (Subwatershed 4) $\left(2.3 \mathrm{~km}^{2}\right)$ illustrating the percent change (a) in peak flow rate $\left(\mathrm{mm} \mathrm{hr}^{-1}\right)$ and (b) in sediment yield $\left(\mathrm{kg} \mathrm{ha}^{-1}\right)$ derived from implementing a brush management practice to remove Creosotebush along with a companion reseeding conservation practice aimed at restoring the native desert grassland community.

(a)

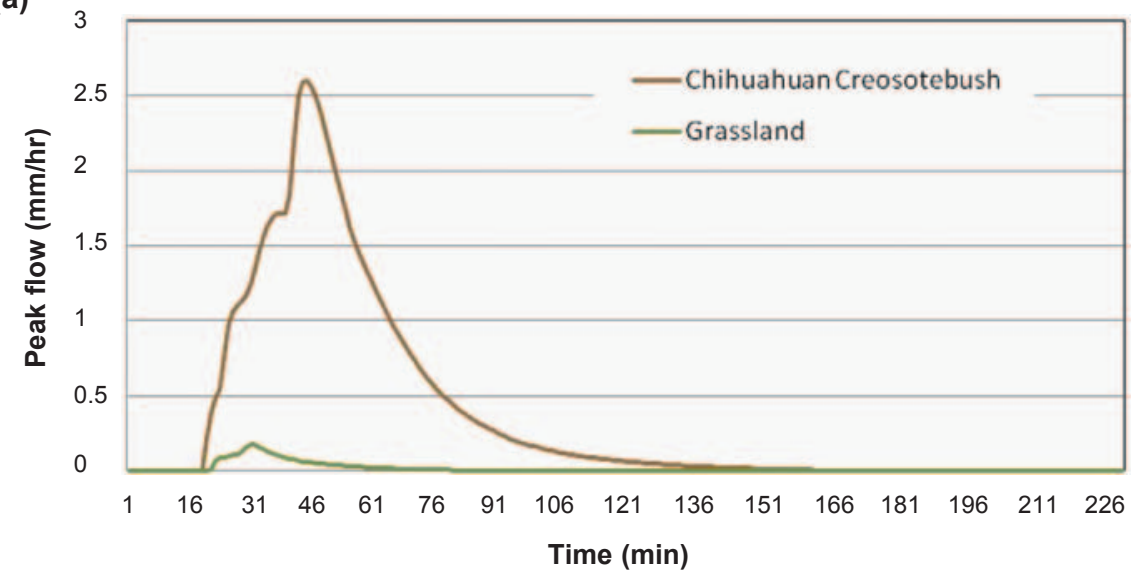

(b)

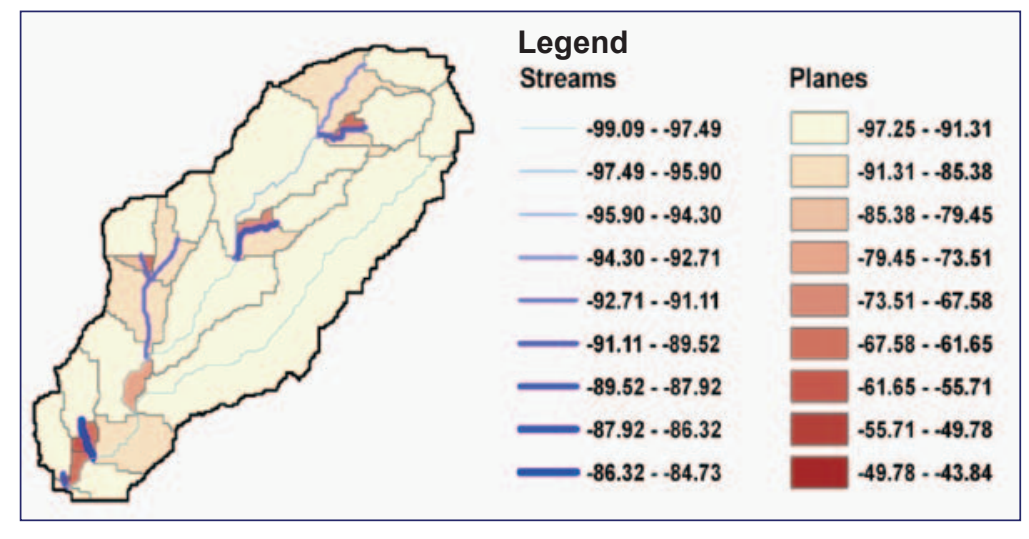

\section{Table 3}

Southwest Regional Gap Analysis Project land cover characteristics for conversion of brush-dominated watershed to a grass-dominated watershed, Tombstone, Arizona.

\begin{tabular}{llll}
\hline Name & Cover (\%) & Canopy interception (mm) & Manning's n \\
\hline $\begin{array}{l}\text { Chihuahuan Creosotebush, Mixed } \\
\begin{array}{l}\text { Desert, and Thorn Scrub } \\
\text { Grassland }\end{array}\end{array}$ & 25 & 3 & 0.055 \\
\hline
\end{tabular}

flow is illustrated in figure 3. Peak flow in the channels after conversion to grassland was reduced by $72 \%$ to $98 \%$, with similar reductions in average annual runoff and sediment yield.

\section{BUFFER STRIP ASSESSMENT: USDA} ARS REYNOLDS CREEK EXPERIMENTAL WATERSHED, BOISE, IDAHO

AGWA was used to set up, parameterize, and execute the KINEROS watershed model using pre- and post-buffer installation and a 5-year, 30-minute design storm on the $238 \mathrm{~km}^{2}(58,811 \mathrm{ac})$ Reynolds Creek Experimental Watershed, located in southwestern Idaho. The hypothetical post-buffer installation simulates 5-meter stream buffers on each side of the stream. The buffer strips are converted to grasslands with $80 \%$ cover and a Manning's $N$ value of 0.15 , up from a watershed average of 0.05 . The buffer strips are located on 


\section{Figure 4}

Spatially distributed post-buffer strip installation watershed response in percent change of (a) total runoff $\left(\mathrm{m}^{3}\right)$ and (b) sediment yield $\left(\mathrm{kg} \mathrm{ha}^{-1}\right)$ from pre-buffer response for the $238 \mathrm{~km}^{2}$ Reynolds Creek Experimental Watershed, Boise, Idaho.

(a)

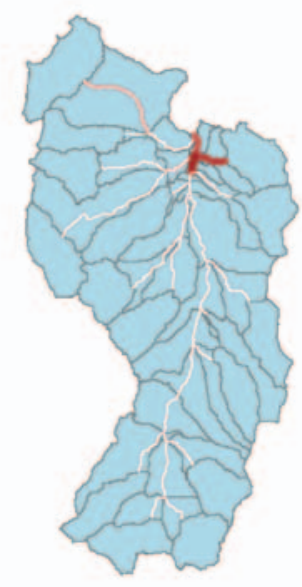

(b)

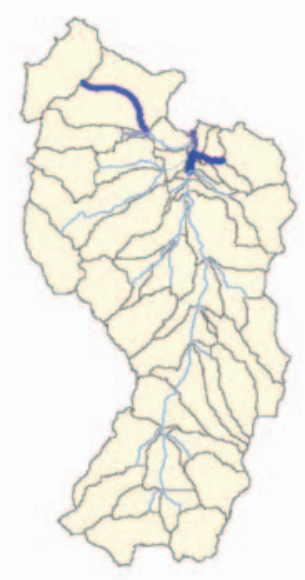

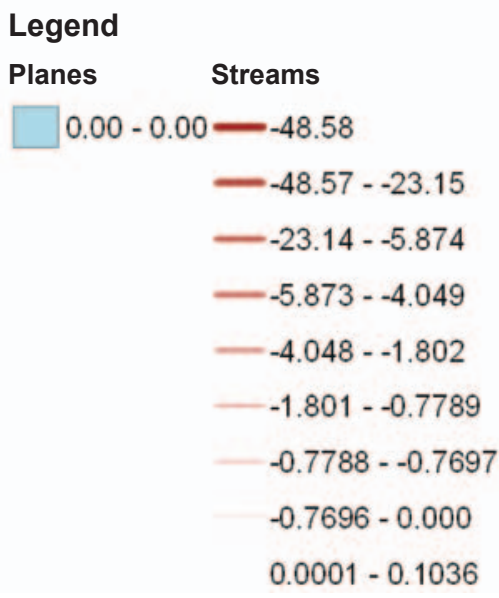

Legend

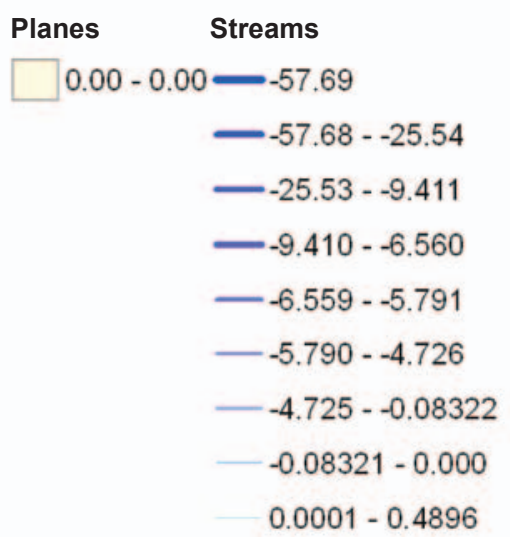

yield; however, buffer strips are capable of making a much larger impact closer to headwaters where channel processes are not yet dominant (figure 4).

Buffer strips can enhance infiltration within the buffer, thereby reducing total runoff, sediment yield, peak sediment discharge, and nutrient and pesticide movement out of the watershed. Buffer placement and design can target problematic agricultural zones where increased sediment,nutrient, and pesticide movement typically occur. Pre-buffer simulations can be used to identify areas already prone to high erosion, and post-buffer simulations can estimate the effectiveness of buffer placement and design. In practice, buffers would not be placed on all channels, but doing so in a simulation, as was done here, allows identification of where the most effective placement would be.

\section{POST-FIRE WATERSHED ASSESSMENT: ROCK CREEK WATERSHED, BATTLE MOUNTAIN, NEVADA}

In August of 2001, the Hot Lakes and Buffalo wildfires in northern Nevada burned $236 \mathrm{~km}^{2}$ (58,316 ac), or roughly $10 \%$ of the $2,237 \mathrm{~km}^{2}(552,774 \mathrm{ac})$ of the Rock Creek Watershed near Battle Mountain, Nevada (figure 5). AGWA was used to set up, parameterize, and execute the SWAT watershed model using preand post-fire land cover data and observed precipitation and climate inputs from year 2000. The pre- and post-fire simulations are retained for each watershed model element (hillslope contributing areas and channels). Percent difference in pre- and post-fire surface runoff, sediment yield, and sediment load (figure 6) for each of the hillslope contributing areas can then be mapped back into the GIS-based spatial watershed representation. The analysis illustrates that the northern burn area dominates the hydraulic response in the year following the fire where annual runoff volume in post-fire conditions can be up to $100 \%$ greater than in prefire conditions. Sediment yield in post-fire conditions can be up to $125 \%$ greater than in pre-fire conditions, and sediment load can be $50 \%$ greater than in pre fire-fire conditions. The use of the AGWA tool facilitates the ready identification of highly impacted upland areas and their downstream impacts and allows the focused implementation of post-fire mitigation and conservation practices.

The pre- and post-fire map-based watershed model differences can be used to target post-fire conservation and management practices in either uplands or channels. Ideally, to enable rapid postfire assessments to directly aid watershed planners in deploying mitigation conservation practices, AGWA and the SWAT or KINEROS2 model could be set up and run for pre-fire (current land cover) conditions for watersheds of interest. That way the necessary topographic data, soils, climate, weather, and current land use and land cover data have been collected and geo-referenced, and the model dis- 


\section{Figure 5}

Area outlined in black on the map illustrates the spatial location and extent of wildfire in the Rock Creek Watershed near Battle Mountain, Nevada, from August of 2001 Hot Lakes and Buffalo wildfires.
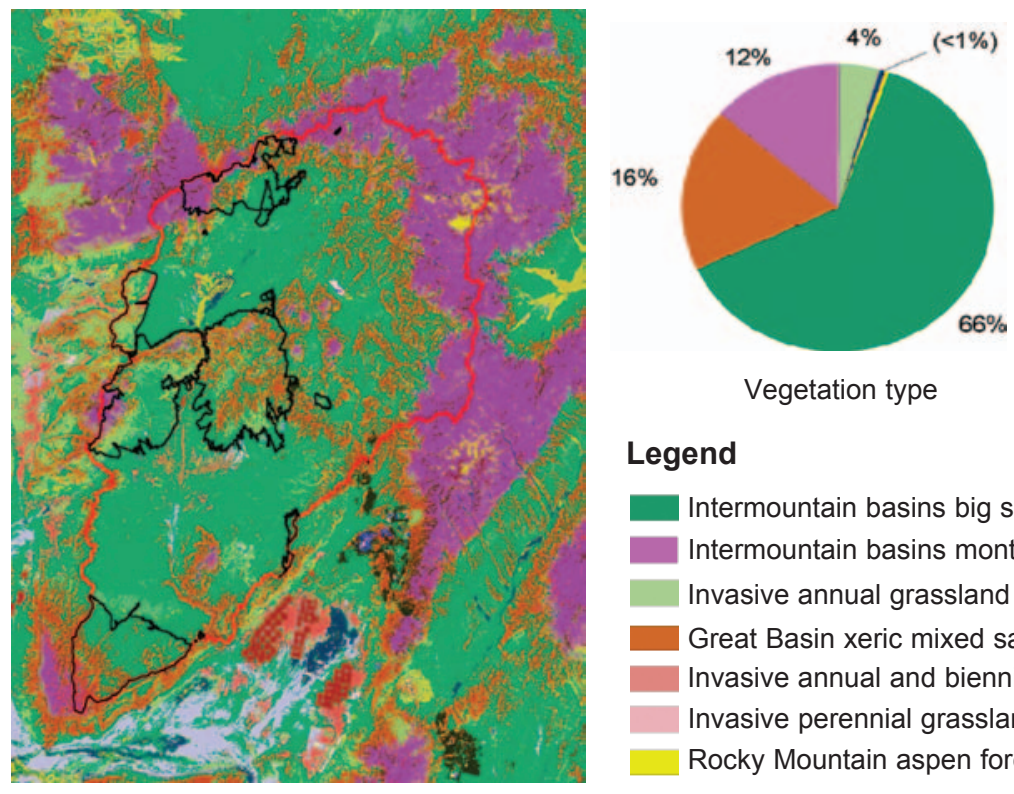

\section{Legend}

Intermountain basins big sagebrush shrubland

Intermountain basins montane sagebrush steppe

Invasive annual grassland

Great Basin xeric mixed sagebrush shrubland

Invasive annual and biennial forbland

Invasive perennial grassland

Rocky Mountain aspen forest and woodland

\section{Figure 6}

Change detection maps from Automated Geospatial Watershed Assessment illustrating the spatial location and magnitude of pre- and post-fire (a) surface runoff, (b) sediment yield, and (c) sediment load resulting from the August of 2001 Hot Lakes and Buffalo wildfires in the Rock Creek watershed near Battle Mountain, Nevada.

(a)

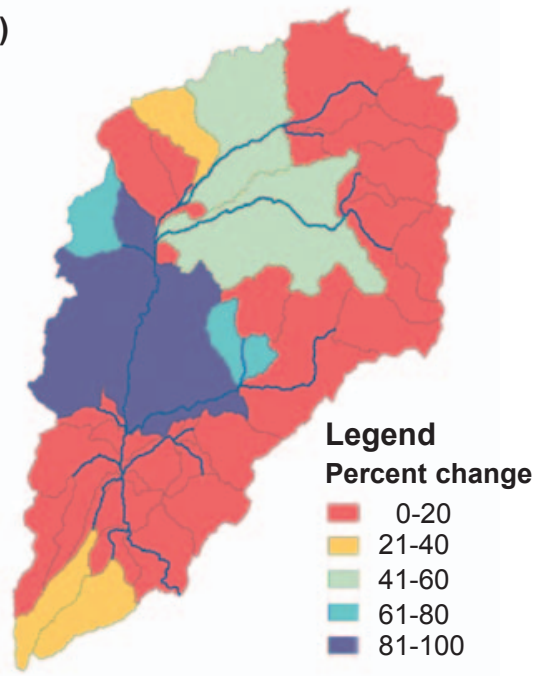

(b)

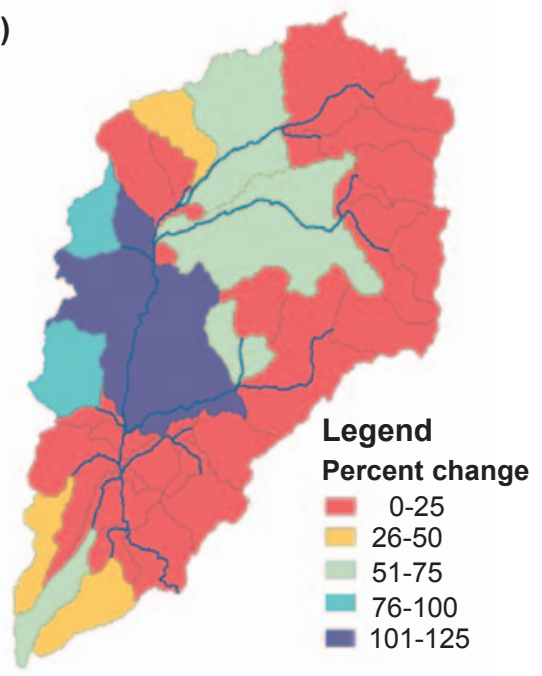

$0510,20 \mathrm{Km}$ (c)

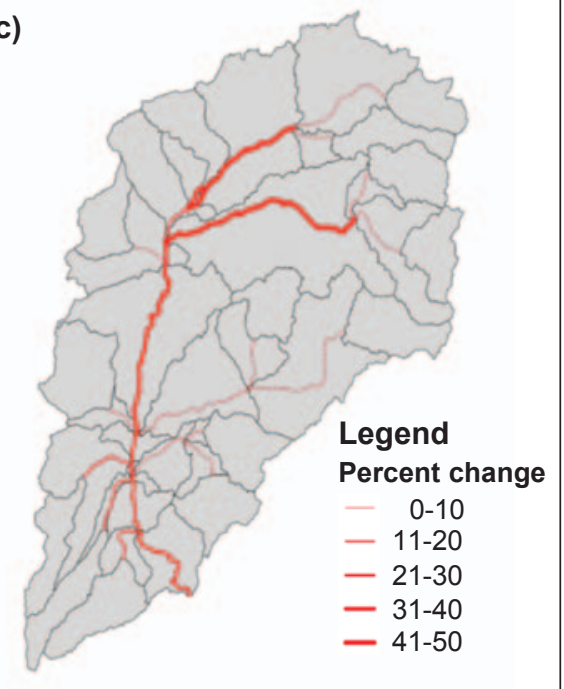

cretization, parameterization, and initial execution have been completed. Outputs from this initial watershed simulation could be spatially examined to identify areas that may be prone to flooding or high erosion under current conditions to target preventative conservation measures.
If a fire were to occur, the burn severity map produced immediately after the fire by watershed planners can be imported directly into AGWA once geo-referenced. Research has been conducted (Canfield et al. 2005; Goodrich et al. 2005) to estimate post-burn infiltration and hydraulic roughness parameters as a function of burn severity. These values are already contained within AGWA look-up tables. This allows immediate post-fire watershed simulation driven by the same climatic inputs as the pre-fire simulation, differencing of the simulations, and spatial display of the dif- 


\section{Figure 7}

Spatially distributed post stock pond installation watershed response in percent change of (a) total runoff $\left(\mathrm{m}^{3}\right)$ and (b) sediment yield $\left(\mathrm{kg} \mathrm{ha}^{-1}\right)$ from pre-pond response for the 150 km2 Walnut Gulch Experimental Watershed, Tombstone, Arizona.

(a)

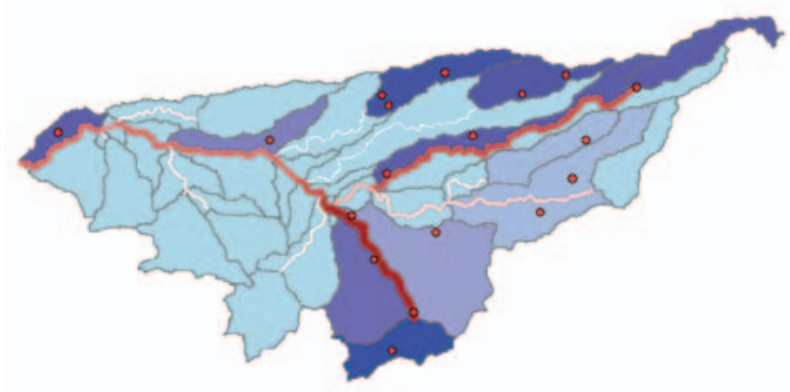

(b)

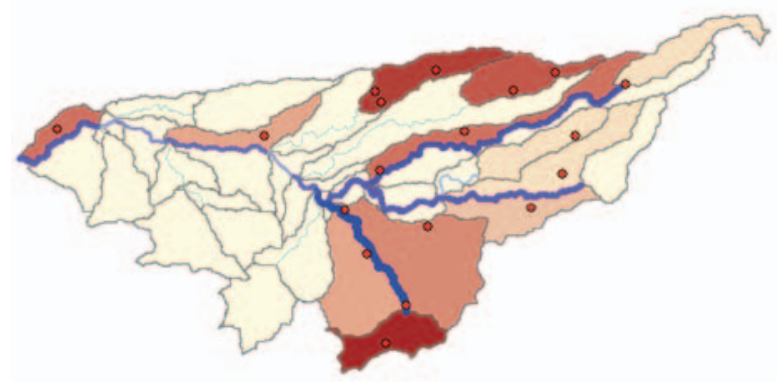

\section{Legend}

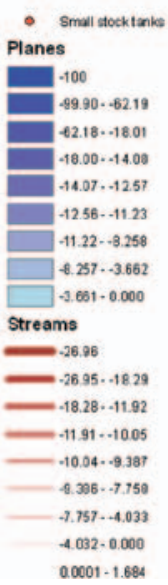

Legend

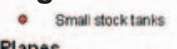

Planes

[-100

$-99.90 \cdots 69.36$

$-69.35 \cdots 29.61$

$-29.60 \cdot-23.71$

$-23.70 \cdot .19 .71$

$19.70 \cdots 17.88$

$\square \cdot 17.87 \cdot 14.36$

$-14.35 \div-6.945$

6.9.94 - 0.000000000

Streams

$-32.76$

$-32.75 \cdot 20.60$

$-20.67 \cdot-15.06$

$-12.58 \cdots 11.69$

$-11.68 \cdot 11.34$

$-11.33 * 10.59$

$-10.58 \cdots 1.966$

$-1.965-1.713$
$-15.05 \div 12.59$ ferences. Watershed planning teams would then be able to target and deploy postfire conservation and mitigation efforts. Fire models could also be employed to derive a series of hypothetical burn severity maps. With the aid of AGWA, these burn scenarios could be used to also identify where pre-fire thinning or controlled burns should be conducted to reduce fire hazards, as well as minimize erosion and downstream flooding.

\section{STOCK POND ASSESSMENT: USDA} ARS WALNUT GULCH EXPERIMENTAL WATERSHED, TOMBSTONE, ARIZONA

AGWA was used to set up, parameterize, and execute the KINEROS watershed model with and without a stock pond configuration using a 5-year, 30-minute design storm on the $150 \mathrm{~km}^{2}(37,066 \mathrm{ac})$ Walnut Gulch Experimental Watershed located in southeastern Arizona. The stock ponds example uses fifteen existing retention structures that typically do not produce any outflow. The fifteen existing retention structures are located on the hillslopes; consequently, because they are designed for retention and effectively capture all runoff above the structures, runoff volumes at the outlet are directly affected by the amount of area behind the stock ponds.

The pre- and post-pond simulations are retained for each watershed model element (hillslope contributing areas and channels). Percent differences in water- shed response for each of these elements for a variety of model outputs (figure 7) can then be mapped back into the GIS-based spatial watershed representation. This enables ready identification of effective stock pond placement for a variety of objectives (e.g., reducing runoff, sediment yield, peak flow, or peak sediment discharge).

The outlet of the watershed saw reductions of $10.33 \%$ in total runoff, $10.06 \%$ in peak flow, and $12.89 \%$ in sediment yield, with the differences most significant at gauging stations closer to the placement of the ponds. Stock ponds can be designed as detention or retention structures. As a detention structure, stock ponds alter the timing of runoff, indirectly increasing infiltration and reducing total runoff, peak flows, and flooding. As a retention structure, stock ponds also capture runoff directly. Stock ponds also reduce sediment yields and peak sediment discharges as water is detained or retained. AGWA can be used to determine the effectiveness of stock pond placement as location will affect timing and total capture differently.

\section{WILDLIFE HABITAT ASSESSMENT:} DESERT SOUTHWEST

Biodiversity has been defined in many ways, but generally refers to the variety of life and the ecological processes that support life (Ridder 2008). Coupling biodiversity perspectives with levels of conservation planning of natural systems have existed for many years (Burley 1988; Goldman and Tallis 2009). This concept has been developed broadly for biodiversity conservation purposes (Gap Analysis Program [GAP])in the continental United States (Scott et al. 1993, 1996; Prior-Magee et al. 2007). GAP provides a landscapelevel process for assessing conservation of biological diversity (Scott et al. 1993, 1996). GAP analysis maps the distribution of plant communities and predicts suitable habitat for animal species and compares these distributions with land stewardship to identify biotic elements at potential risk of endangerment. The GAP effort provides methods and data to analyze the ecological context of biotic elements and the current conservation status at regional and national efforts with available national 
land cover (http://www.gap.uidaho.edu/ landcoverviewer.html) to assess the impact of conservation on species habitat suitability models for 2,094 species nationally (http://www.nbii.gov/portal/server.pt/ community/maps and data/1850/species modeling/7000).

Habitat suitability models for 817 terrestrial vertebrate species in the Southwest were developed as part of SWReGAP (Boykin et al. 2007, 2010). These suitability models will be used to create a series of biodiversity metrics. These data layers do not track or contain information of the condition of land cover within a cover class. To address the effects and benefits of conservation practices on cover condition, inductive models using species observation records will be developed using NRCS National Rangeland Inventory data (Spaeth et al. 2003, 2005). These models will be developed for a number of selected species and rangeland conservation practices (e.g., prescribed fire, brush removal, water points) and displayed at the eight-digit Hydrologic Unit Code (HUC) watershed level using AGWA.This will allow us to evaluate how a proposed conservation practice would impact and benefit a suite of wildlife species as well as other ecosystem services (soil erosion, water availability, and forage availability) (figure 8).

\section{SUMMARY AND CONCLUSION}

During its first five years, Grazing Land CEAP established research and assessment efforts designed to estimate the effects and benefits of conservation practices through a combination of research, data collection, model development, and model application over a range of scales (i.e., pasture to watershed to river basin). Grazing Land CEAP has successfully developed hillslope scale soil erosion models for water and wind erosion, as well as approaches and methodologies to produce scientifically credible estimates of environmental benefits and impacts of conservation on grazing lands at the hillslope scale (RHEM) and watershed scale using the KINEROS, SWAT, and AGWA models. The next major steps for Grazing Land CEAP are as follows:

\section{Figure 8}

Terrestrial vertebrate species richness based on eight-digit Hydrologic Unit Code watershed level for desert southwest region using Southwest Regional Gap Analysis Project data.

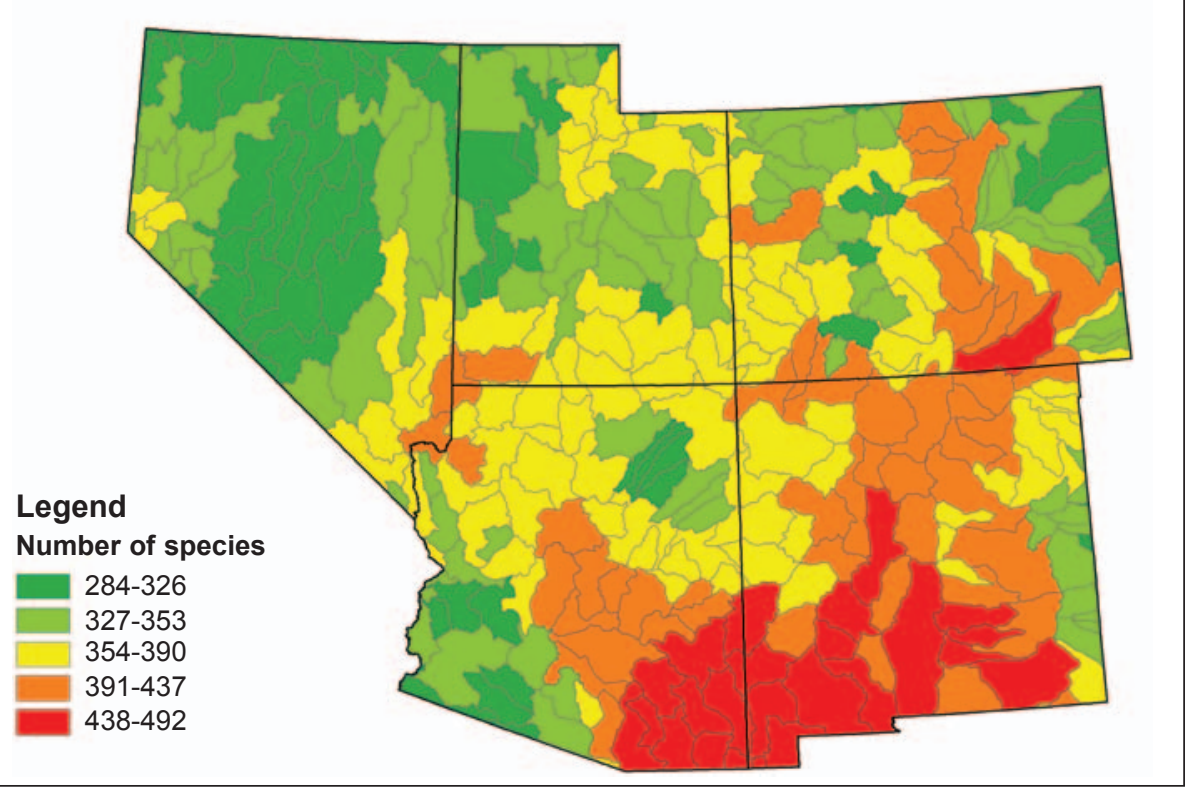

- Develop databases to accurately describe the distribution of plant communities across the west at a scale that we can measure the impact of conservation.

- Develop database to accurately describe the bio-physical attributes (i.e., plant canopy cover, ground cover, species, standing biomass) within each plant community (vegetation polygon).

- Develop database to document the type and placement of conservation practices across the landscape.

- Develop means of documenting additional conservation benefits, such as soil quality and the social and economic benefits of conservation.

Grazing Land CEAP findings and results will be used to report progress on the environmental effects of USDA conservation programs, aid discussions on conservation policy development, guide conservation program implementation, and ultimately help ranchers and land managers make informed conservation choices based on sound science. Anticipated products and impact of the Grazing Land CEAP work include the following:

- Development of new site-specific risk assessment tools specifically designed and validated for use on rangelands.
- Development of watershed assessment tools designed to estimate optimal conservation practice type and placement to minimize conservation investments and maximize cumulative conservation benefit over a range of scales.

- Determination of the status and extent of nonfederal western rangelands.

- Development of a database for national, regional, and local assessments.

- Documentation of management practices currently in place.

- Assessment of unmet conservation needs on western grazing lands.

\section{ACKNOWLEDGEMENTS}

Support for this research as provided by the USDA Rangeland Research Program and the USDA Natural Resources Conservation Service Conservation Effects Assessment Program. USDA is an equal opportunity provider and employer.

\section{REFERENCES}

Boykin, K.G., B.C. Thompson, R.A. Deitner, D Schrupp, D. Bradford, L. O'Brien, C. Drost, S. Propeck-Gray, W. Rieth, K.A. Thomas, W. Kepner, J. Lowry, C. Cross, B. Jones, T. Hamer, C. Mettenbrink, K.J. Oakes, J. Prior-Magee, K. Schulz, J.J. Wynne, C. King, J. Puttere, S. Schrader, and Z. Schwenke. 2007. Predicted animal habitat distributions and species richness. Chapter 3 In 
Southwest Regional Gap Analysis Final Report, eds. J.S. Prior-Magee, et al. Moscow, ID: US Geological Survey, Gap Analysis Program.

Boykin, K.G., B.C. Thompson, and S. PropeckGray. 2010. Accuracy of southwest regional gap analysis project habitat models in predicting physical features for habitat associations. Ecological Modeling 221:2769-2775.

Burley, F.W. 1988. Monitoring biological diversity for setting priorities in conservation. In Biodiversity. ed. E.O. Wilson. Washington, DC: National Academies Press.

Canfield, H.E., Goodrich, D.C., and I.S. Burns. 2005. Application of models to predict post-fire runoff and sediment transport at the watershed scale in southwestern forests. In Proceedings of the American Society of Civil Engineers. 2005 Watershed Management Conference, Williamsburg,Virginia, July 22-25, 2005.

Gassman, P.W., M.R. Reyes, C.H. Green, and J. G. Arnold. 2007. The soil and water assessment tool: historical development, applications, and future directions. American Society of Agricultural and Biological Engineers 50:1211-1250.

Goodrich, D.C., H.E. Canfield, I.S. Burns, D.J. Semmens, S.N. Miller, M. Hernandez, L.R., Levick, D.P. Guertin, and W.G. Kepner. Rapid post-fire hydrologic watershed assessment using the AGWA GIS-based hydrologic modeling tool. In Proceedings of the American Society of Civil Engineers. 2005 Watershed Management Conference, Williamsburg,Virginia, July 22-25, 2005.

Goldman, R.L., and H. Tallis. 2009. A Critical Analysis of Ecosystem Services as a Tool in Conservation Projects, The Possible Perils, the Promises, and the Partnerships. Year in Ecology and Conservation Biology 2009. Annals of the New York Academy of Sciences 1162:63-78.

Herrick, J.E., V.C. Lessard, K.E. Spaeth, P.L. Shaver, R. S. Dayton, D.A. Pyke, L. Jolley, and J.J. Goebel. 2010. National ecosystem assessments supported by scientific and local knowledge. Frontiers in Ecology and the Environment. doi:10.1890/100017.

Landfire. 2011. http://www.landfire.gov.

Miller, S.N., D.J. Semmens, D.C. Goodrich, M. Hernandez, R.C. Miller, W.G. Kepner, D.P. Guertin. 2007. The Automated Geospatial Watershed Assessment Tool. Environmental Modeling and Software 22:365-377.

Mitchell, J.E. 2000. Rangeland resource trends in the United States: A technical document supporting the 2000 USDA Forest Service RPA Assessment. Gen. Tech. Rep. RMRS-GTR-68. Fort Collins,
CO: USDA Forest Service, Rocky Mountain Research Station.

North American Land Cover (NALC). 2011. http:// landcover.usgs.gov/landcoverdata.php.

Nearing, M.A., H. Wei, J.J. Stone, F.B. Pierson, K.E. Spaeth, M.A. Weltz, and D.C. Flanagan. 2011. A rangeland hydrology and erosion model. Transaction of American Society of Agricultural and Biological Engineers 54:1-8.

NRC (National Research Council). 1994. Rangeland health: New methods to classify, inventory and monitor rangelands. Washington, DC: National Academy Press.

Nusser, S.M., and J.J. Goebel. 1997. The national resources inventory: A long-term multi-resource monitoring program. Environmental and Ecological Statistics 4:181-204.

Nusser, S.M., F.J. Breidt, and W.A. Fuller. 1998. Design and estimation for investigating the dynamics of natural resources. Ecological Applications 8:234-245.

Prior-Magee, J.S., K.G. Boykin, D.F. Bradford, W.G. Kepner, J.H. Lowry, D.L. Schrupp, K.A. Thomas, and B.C. Thompson, eds. 2007. Southwest Regional Gap Analysis Project Final Report. Moscow, ID: US Geological Survey, Gap Analysis Program.

Ridder, B. 2008. Questioning the ecosystem services argument for biodiversity conservation. Biodiversity and Conservation 17: 781-790.

Scott, J.M., F. Davis, B. Csuti, R. Noss, B. Butterfield, C. Groves, H. Anderson, S. Caicco, F. D'Erchia, T.C. Edwards Jr., J. Ulliman, and R.G. Wright. 1993. Gap analysis: A geographical approach to protection of biological diversity. Wildlife Monographs 123.

Scott, J.M., T.H. Tear, and F.W. Davis, eds. 1996. Gap analysis - a landscape approach to biodiversity planning. Bethesda, MD: American Society of Photogrammetry and Remote Sensing.

Smith, R.E., D.C. Goodrich, and J.N. Quinton. 1995. Dynamic, distributed simulation of watershed erosion: The KINEROS2 and EUROSEM models. Journal of Soil and Water Conservation 50(5):517-520.

Southwest Regional Gap Analysis Project (SWReGAP). 2011. http://fws-nmcfwru.nmsu. edu/swregap.

Spaeth, K.E., G.L. Peacock, J.E. Herrick, P. Shaver, and R. Dayton. 2005. Rangeland field data techniques and data applications. Journal of Soil and Water Conservation 60(5):114A-119A.

Spaeth, K.E., F.B. Pierson, J.E. Herrick, P.L. Shaver, D.A. Pyke, M. Pellant, D. Thompson, and B. Dayton. 2003. New proposed national resources inventory protocols on nonfederal rangelands. Journal of Soil and Water Conservation 58(1):18A-21A.

Srinivasan,R. X. Zhang, and J. Arnold. 2010. SWAT Ungauged: Hydrological budget and crop yield predictions in the Upper Mississippi River Basin. American Society of Agricultural and Biological Engineers 53:1533-1546.

USDA. 2009. Summary Report: 2007 National Resources Inventory. Washington, DC: Natural Resources Conservation Service; Ames, Iowa: Center for Survey Statistics and Methodology, Iowa State University. http://www.nrcs.usda. gov/Internet/FSE_DOCUMENTS//stelprdb1041379.pdf.

USDA. 2011. RCA Appraisal 2011. Soil and Water Resources Conservation Act. 2011. Prepublication. ftp://ftp-fc.sc.egov.usda.gov/NHQ/ rca/2011_RCA_Appraisal_Pre_Publication_ Copy.pdf.

USDA NRCS (USDA Natural Resources Conservation Service). 2007. National Resources Inventory. NRI Rangeland Field Study Handbook of Instructions. Washington, DC: USDA Natural Resources Conservation Services. USDA NRCS. 2010. Assessment of the Effects of Conservation Practices on Cultivated Cropland in the Upper Mississippi River Basin. ftp:// ftp-fc.sc.egov.usda.gov/NHQ/nri/ceap/ UMRB_final_draft_061410.pdf.

USDA NRCS. 2011a. Grazing Lands National Assessment. http://www.nrcs.usda.gov/wps/ portal $/ \mathrm{nrcs} /$ detail $/$ ?ss=16\&navtype $=$ BROWS EBYSUBJECT \&cid=NRCS143_014159\&n avid $=960120000000000 \&$ pnavid $=960000000$ $000000 \&$ position $=$ SubFeature $\star \&$ ttype $=$ detail \&pname $=$ Grazing $\% 20$ Lands $\% 20$ National $\% 20$ Assessment $\% 20 \mid \% 20$ NRCS.

USDA NRCS. 2011b. Assessment of the Effects of Conservation Practices on Cultivated Cropland in the Chesapeake Bay Region. http://www. nrcs.usda.gov/Internet/FSE_DOCUMENTS/ stelprdb1042076.pdf.

Weltz, M.A., L. Jolley, M. Nearing, J. Stone, D. Goodrich, K. Spaeth, J. Kiniry, J. Arnold, D. Bubenheim, M. Hernandez, and H. Wei. 2008. Assessing the benefits of grazing land conservation practices. Journal of Soil and Water Conservation 63(6):214A-217A. 